\title{
Prevalence Of Low Calorie Intake By Rural Families In Palpa District Of Nepal
}

\author{
Ghimire, Madhusudan* ${ }^{1}$, Ghimire, Moushami ${ }^{2}$ \\ ${ }^{1}$ Asistant Professor, Department of Community Medicine,Lubmini Medical College, Palpa. \\ ${ }^{2}$ Lecturer, Department of Community Medicine,Lubmini Medical College, Palpa.

\section{Abstract}

Healthy population is indispensable for national development. Adequate food intake by people is the key determinant to keep up their health. Malnutrition nevertheless remains pervasive in developing countries, undermining people's health, productivity, and often their survival. Food insecurity and hunger remain persistent in Nepal, prevalence of low calories intake by rural family is widespread throughout the country population. Mainly marginalized communities, ethnic group with poor economic status, traditional societies and lower cast people are exposed to food deficit. The cross-sectional study was designed to investigate the prevalence of low calories intake by rural families and its associated determinants in Palpa district of Nepal at 2012. A random sample of 339 families was selected from rural areas (DUMRE, DAMKADA and TELGHA villages) of this district. Data were analyzed by using the SPSS software for Windows (version 16.0). The existence of inadequate food calorie intake among rural families was most common. Most of them were fall under the malnutrition. The study concluded that calorie intake of ethnic group was significantly higher than other groups

Key Words: Demographic veriables, low food calories intake,Malnutrition and palpa district

\section{INTRODUCTION}

$\mathrm{F}$ reedom to work and the right to enjoy a healthy life are enshrined in the constitutions of most of the countries as fundamental rights of its citizens. However this freedom does not always guarantee enjoyment of good health for the poor citizens of many developing countries. Most of the developing nations are plagued by problems of under nutrition and a host of infections [1]. Nutrition is an input to and foundation for health and development. Better nutrition is a prime entry point to ending poverty and a milestone to achieving better quality of life[2] Adequate nutrition is essential in early childhood to ensure healthy growth, proper organ formation and function, a strong immune system and neurological and cognitive development $[3,4]$.

Undernutrition leads to increased mortality and morbidity which lead to loss of economic output and increased spending on health, individuals are less productive (both due to physical and mental impairment), and that children benefit less from education[5]. Inadequate nutrition is perhaps the most important problem facing the poor people in the world today. In spite of the progress made in improving nutrient availability in the last decade, a large proportion of poor households in developing countries still have inadequate access to sufficient food[6]. Although per capita daily calorie intake in developing countries has increased substantially in the last decade, the number of undernourished people is still around 923 Million and the recent food price increases has also triggered an increase in hunger worldwide.[7]

Malnutrition is a complex condition that can involve multiple, overlapping deficiencies of protein, energy and micronutrients. The underlying causes are illnesses, poor dietary intake, lack of sanitation and hygiene, lack of mothers' education, lack of awareness, lack of appropriate education, cultural practices and taboos, women's low social status, poor transport linkages and low levels of agricultural technology, lack of

\section{Address for correspondence*}

Dr. Madhusudan Grimier,

Asistant Professor, Department of Community

Medicine,Lubmini Medical College, Palpa.

Email: madhumds@gmail.com political will to improve the situation and inadequate complementary feeding.[8,9] Protein energy malnutrition (PEM) remains a major public health problem in Nepal to such extent that it is the most common cause of childhood morbidity and mortality. Nepal has a very high rate of child malnutrition: half $(49 \%)$ of children under five are stunted and one third $(39 \%)$ are underweight. Maternal undernutrition is also a significant problem in Nepal. The economic costs of malnutrition are very high - an estimated 2-3\% of GDP[10]. Since 1990, at national level, overall food production is deficit and Nepal has been a net cereal importer for most years during the last two decades[11]. Poverty and malnutrition in Nepal are characterized by considerable regional and ethnic variation[12].

\section{MATERIALSAND METHODS}

The cross-sectional study was designed to investigate the prevalence of low calories intake by rural families in palpa district of Nepal at 2012. Sample size of 339 was calculated assuming margin of error 5\%, non-response rate $10 \%$ with $95 \%$ confidence interval (CI). A random sample of 339 families was selected from rural areas (DUMRE, DAMKADA, TELGHA villages) of this district. After getting the consent form concern authorities, local people and respondents, a structured questionnaire and checklist of food items (rice/wheat, potato, pulses, meat, fish, milk, eggs, vegetables, and fruits) were used to collect information (amount of continue three-day food consumed by family) from head of household(Data collection period was April to Jun of 2012). Actual intake of calories by families was compared with the multiplication result of Expected Calories Consumption and consumption unit. Data were analyzed by using the SPSS software for Windows (version 16.0). Chi-square test was used to find out association of ordinal veriables as: family type, house type, occupation and cast, with nutritional outcome. The study was concerned to maintain anonymity of the respondent's views and their wishes.

\section{RESULTS}

1.SOCIO-DEMOGRAPHIC CHARACTERISTICS OF THE STUDY SUBJECTS:

\section{PREVALENCE OF MALNUTRITION AMONG THE FAMILIES}


Socio-demographic Characteristics Of The Study Subjects:

\begin{tabular}{|c|c|c|c|}
\hline \multirow{5}{*}{$\begin{array}{l}\text { 1. Age of the head } \\
\text { of household }\end{array}$} & Age in Years & Percent & $\mathrm{N}=339$ \\
\hline & $30-40$ & 32.8 & \multirow{4}{*}{$\begin{array}{c}\text { Mean }=49.238 \text { years } \\
\text { Std. } \\
\text { Deviation }=1.116 \\
\text { years }\end{array}$} \\
\hline & $41-50$ & 37 & \\
\hline & $51-60$ & 19.8 & \\
\hline & Above 60 & 10.4 & \\
\hline \multirow[t]{2}{*}{ 2. Family type } & Nuclear & $234(69.0)$ & \\
\hline & Joint & $105(31.0)$ & \\
\hline \multirow[t]{5}{*}{ 3. Caste } & Brahmin & $60(17.7)$ & \\
\hline & Kshetri & $66(19.5)$ & \\
\hline & Magar & $142(41.9)$ & \\
\hline & Schedule cast & $53(15.6)$ & \\
\hline & Janajati (except Magar) & $18(5.3)$ & \\
\hline \multirow[t]{2}{*}{ 4. House type } & Kaccha & $162(47.8)$ & \\
\hline & Pucca & $177(52.2)$ & \\
\hline \multirow[t]{5}{*}{ 5. Occupation } & Unemployed & $32(9.4)$ & \\
\hline & Teacher & $32(9.4)$ & \\
\hline & Farmer & $82(24.2)$ & \\
\hline & Business & $117(34.5)$ & \\
\hline & Others & $76(22.4)$ & \\
\hline
\end{tabular}

Prevalence Of Malnutrition Among The Families

Prevalence of mainutrition among families

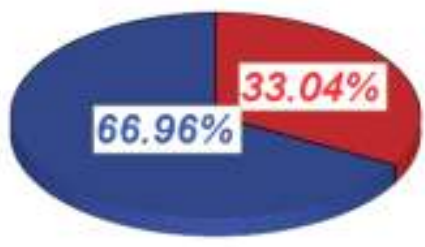

\section{DISCUSSION}

Dietary assessment is a process designed to determine what kinds of foods a person is consuming and in what amounts. The present study was conducted to find out whether families are meeting their dietary needs and to identify association between demographic veriables and nutritional outcome. United Nations Universal Declaration of Human Rights 1948 Article 25 stated that "Everyone has the right to a standard of living adequate for the health and well-being of himself and his family, including food, clothing, and housing and medical care and necessary social services, and the right to security in the event of unemployment,

Impact Of Demographic Veriables On Nutritional Status Of The Family

$$
\mathbf{N}=\mathbf{3 0 0}
$$

\begin{tabular}{|c|c|c|c|c|}
\hline \multirow{2}{*}{$\begin{array}{l}\text { 1. Family } \\
\text { type }\end{array}$} & & \multicolumn{3}{|c|}{ Calories intake } \\
\hline & & Less than $2400 \mathrm{Kcl}$ & $2400 \mathrm{Kcl}$ & Total \\
\hline & nuclear & 122 & 112 & 234 \\
\hline & joint & 105 & 0 & 105 \\
\hline \multicolumn{5}{|c|}{ Pearson Chi-Square value (75.053), $d f(1),(p=0.000)$} \\
\hline \multirow[t]{5}{*}{ 2. Caste } & Brahmin & 23 & 37 & 60 \\
\hline & Chhetri & 66 & 0 & 66 \\
\hline & Magar only & 67 & 75 & 142 \\
\hline & Schedule cast & 53 & 0 & 53 \\
\hline & indigenous & 18 & 0 & 18 \\
\hline \multicolumn{5}{|c|}{ Pearson Chi-Square value (1.149) df(4), $(p=0.000)$} \\
\hline \multirow{5}{*}{$\begin{array}{l}\text { 3. Occupat } \\
\text { ion }\end{array}$} & unemployed & 32 & 0 & 32 \\
\hline & teacher & 11 & 21 & 32 \\
\hline & farmer & 82 & 0 & 82 \\
\hline & business & 71 & 46 & 117 \\
\hline & others & 31 & 45 & 76 \\
\hline \multicolumn{5}{|c|}{ Pearson Chi-Square value (97.222), $d f(4),(p=0.000)$} \\
\hline \multirow{2}{*}{$\begin{array}{l}\text { 4. } \begin{array}{l}\text { House } \\
\text { type }\end{array} \\
\text { typen }\end{array}$} & kaccha & 127 & 35 & 162 \\
\hline & pacca & 100 & 77 & 177 \\
\hline
\end{tabular}


sickness, disability, widowhood, old age or other lack of livelihood in circumstances beyond his control"[13]. But the food and nutrition security remain most fundamental challenge for human welfare and for economic growth. In many countries, sufficient food to meet the needs of all citizens is not even available at a national level[14]. Nepal is a food deficit, land locked and least developed country. Around 49.3 percent of under-five children are chronically malnourished[15]. About 80 per cent of Nepal's people live in rural areas and depend on subsistence farming for their livelihoods. Poor rural people in Nepal generally have large families, very small landholdings or none at all, and high rates of illiteracy, concentrated in specific ethnic, caste and marginalized groups, particularly those of the lowest caste (dalits), indigenous peoples (janajatis) and women. Household food insecurity and poor nutrition are major concerns in these areas[16]. The first health survey of Nepal which was done in 1965/66 among the 6,321 people from 957 households from nineteen different sites of country found that the diet as a whole was lacking in protein, calcium, Vitamin A, riboflavin and ascorbic acid[17]. A random-sampled nutrition survey conducted in Mugu and Humla districts also showed a precarious nutrition situation[18]. National Nutrition Council of Bangladesh estimated that about $45-51 \%$ of the total population in Bangladesh were poor based on their calorie consumption. The prevalence of poverty and resulting low calorie consumption was higher in rural than in urban areas[19]. The calorie intake by people of sub-Saharan Africa found 2098Kcal/capita/day only[20]. Similar situation has observed in other developing countries as: National Sample Survey Organization of India conducted a study during 2004 - 2005 found that average daily intake of calories by rural population had $2047 \mathrm{Kcal}$. [21] Above situations have indicated the food calories intake by rural people in developing countries was found to be low, so it could be key determinant to decline the level of public health in such countries.

Results of the study revealed that, low calories intake among the families was widespread and persistent in rural Palpa. The prevalence of low calories intake by families was to be $66.96 \%$. A study conducted by National Nutrition Monitoring Bureau (NNMB) at different time in India also showed that prevalence of under nutrition in adults was higher in rural areas as compared to urban areas but majority of the urban population who could work in White or blue collar jobs, their energy expenditure for these activities was low, Where average intake of calories by men was $2000 \mathrm{kcal}$ energy/capita/day only[22]. Another survey carried out by NNMB in the rural communities of nine states viz. Kerala, Karnataka, Tamil Nadu, Andhra Pradesh, Maharashtra, Madhya Pradesh, Gujarat, Orissa and West Bengal found that the proportion of preschool children underweight was about $55 \%$, while that of severe underweight was $18 \%$. 33\% males and $36 \%$ females had chronic energy deficiency. Food and nutrient intake levels were relatively lower in Kerala compared to other states, but the prevalence of under nutrition among young children was low[23].

Welfare of a household depends on nature of occupation, socio economic condition house type and family type or size, which in turn is based on the nature of the work of the main household earner. All of these veriables are most important to determine level of calorie consumption[24]. Present study indicated that the demographic variables as: family type, occupation of head of the household and type of house were strongly associated $(\mathrm{p}<0.000)$ with low calories intake by families as compared to the result from a study conducted by Masuma Khatun, SM Ziauddin Hyder, Abbas Bhuiya and Mushtaque Chowdhury in Bangladesh, where the association between occupation of the household head and family size with prevalence of low calorie consumption among the rural families was Significantly $(\mathrm{p}<0.001)$ observable[25].

\section{CONCLUSION}

Most of the indigenous families could spend their life with low calories intake. Nature of occupation, socio economic condition house type and family type or size found to be strong predictors to nutritional outcome in rural communities of Palpa district of Nepal.

\section{REFERENCES}

1. Thomas, Varghese. Health care in developing countries- Need for finance, education or both? Calicut Medical Journal 2009; 7(1): e1.

2. Briend, A and Prinzo, ZW.Dietary management of moderate malnutrition: Time for a change. Food and Nutrition Bulletin. 2009;30(3): $265-266$.

3. Liu L, Johnson HL, Cousens S, Perin J, Scott S, Lawn JE, Rudan I, Campbell H, Cibulskis R, Li M, Mathers C, Black RE, for the Child Health Epidemiology Reference Group of WHO and UNICEF. Global, regional, and national causes of child mortality: an updated systematic analysis for 2010 with time trends since 2000. Lancet. 2012;379:2151-61.

4. Black RE, Allen LH, Bhutta ZA, Caulfield LE, de Onis M, Ezzati M, Mathers C, Rivera J, for the Maternal and Child Undernutrition Study Group. Maternal and child undernutrition: global and regional exposures and health consequences. Lancet 2008;371:243-60.

5. Behrman, J., H. Alderman, and J. Hoddinott. "Hunger and Malnutrition". In B.Lomborg (ed.) Global Crises, Global Solutions. Cambridge (UK): Cambridge University Press. 2004.

6. Abdulai, A and Aubert, D. Nonparametric and parametric analysis of calorie consumption in Tanzania. Food Policy. 2004;29(2): 113-129.

7. FAO. An Introduction to the Basic Concepts of Food Security: Food Security Information for Action Practical Guides. FAO Food Security Programme. 2008.

8. UNICEF. Facts sheet: The state of the world's children. 1998.

9. Food and Agriculture Organization. Assessment of Food Security and Nutrition Situation in Nepal. Food and Agriculture Organization of the United Nations.2010;14.

10. WORLD BANK. Nutrition in Nepal: A National Development Priority. $2012 ; 8$. Retrived from wwwwds.worldbank.org/.../PDF/683780WP0P 1235000 Nutrition0in0Ne 68378.

11. FAO. Nepal Food Security and Nutrition Monitoring/Early System Assessment of Current System, Project Design and Proposal. 2008.

12. Central Bureau of Statistics, Nepal,United Nations World Food Programme, Nepal and The World Bank. Small area estimation of poverty,Caloric intake and malnutrition in Nepal. 2006.p1. 
13. United Nations. United Nations Universal Declaration of Human Rights 1948. Article 25. 1949; 5.

14. Naiken, L. FAO methodology for estimating the prevalence of undernourishment. In Measurement and assessment of food deprivation and undernutrition. Proceedings of an international scientific symposium convened by the Agriculture and Economic Development Analysis Division, Food and Agriculture Organization of the United Nations. 2002;6: 26-28.

15. UNDP. Human Development Report 2009 Overcoming Barriers: Human Ability and Development. Oxford University Press, New York. 2009.

16. United Nations Development Programme's. Rural poverty in Nepal. Human Development Report 2013.

17. Brown ML, Worth RM \& Sha h NK. Health Survey of Nepal. American Journal of Clinical Nutrition. 1968; 21(8): 875-881.

18. United Nations System Standing Committee on Nutrition. Nutrition information in Crisis Situations Report no. 9 Summary Results of a nutrition and mortality survey in Humla \& Mugu districts, Karnali province, Nepal. 2006;5:7.

19. National Nutrition Council. State of nutrition in Bangladesh. BNNC. Dhaka 1995.
20. Cornelia FA van Wesenbeeck, Michiel A Keyzer and Maarten Nubé Estimation of undernutrition and mean calorie intake in Africa: methodology, findings and implications. International Journal of Health Geographics 2009; 8:37.

21. Ministry of Statistics and Programme Implementation of India. National Sample Survey Organization. Nutritional intake in India 2004-05. NSS 61st Round July 2004 - June 2005. NSSO, New Delhi.2007;500.

22. Ramachandran, Prema. Dietary intake, physical activity and nutritional status of Indian adults. NFI Bulletin. 2008;29(3).

23. Brahmam, G.N.V. et al. Diet and nutritional status of population and prevalence of hypertension among adults in rural areas. National Institute of Nutrition Hyderabad. 2006:143.

24. Mizoguchi, T. Socioeconomic Characteristics of Poverty. Asian Development Review (Studies on Asian and Pacific Economic Issues). Asian Development Bank, Philippines. 1990; 8(1): 18-43.

25. Khatun Masuma, Ziauddin Hyder SM, Bhuiya Abbas and Chowdhury Mushtaque. Effect of BRAC's Rural Development Programme on calorie consumption: evidence from Matlab. Working Paper No. 26. BRAC-ICDDR,B Joint Research Project. Bangladesh.1998: 1-8. 